\title{
MITIGASI DAN PENANGANAN \\ BENCANA LINGKUNGAN DI TELUK JAKARTA
}

\author{
MITIGATION AND HANDLING \\ ENVIRONMENTAL DISASTERS IN JAKARTA COASTAL BAY
}

\author{
Andrias Steward Samusamu, Puput Fitri Rachmawati, Renny Puspasari \& Sri Turni Hartati \\ Peneliti Pusat Riset Perikanan, BRSDM - KKP \\ Jl. Pasir Putih 2 Ancol Timur, Jakarta Utara; Tlp/Fax: (021) 64700928/(021) 64700929 \\ e-mail : buce.prpt@gmail.com \\ Diterima tanggal: 11 November 2019; diterima setelah perbaikan: 20 November 2019 ; Disetujui tanggal: 14 Desember 2019
}

\begin{abstract}
ABSTRAK
Wilayah perairan Teluk Jakarta cukup rentan untuk menerima beban berat bahan pencemar baik berupa limbah domestik, organik, industri, logam berat maupun tumpahan minyak yang meningkat dari waktu ke waktu dengan kecenderungan terakumulasi dan mengendap di dasar perairan. Peristiwa kematian massal ikan di perairan Teluk Jakarta merupakan fenomena yang terjadi sebagai dampak dari perubahan kualitas lingkungan perairan. Perubahan ini dapat terjadi secara fisik maupun kimiawi. Penelitian ini akan mencoba menggambarkan fenomena kematian massal ikan di yang merupakan kejadian berulang yang sudah berlangsung lebih dari tiga dasawarsa di Teluk Jakarta. Tujuannya adalah untuk memberikan rekomendasi tentang mitigasi dan adaptasi sebagai langkah strategis dalam pengendalian pencemaran lingkungan sekaligus penanganan yang lebih komperhensif dan tepat terhadap peristiwa kematian massal ikan di Teluk Jakarta. Metode yang digunakan dalam penelitian adalah studi literature dan pertemuan kooperatif antar instansi terkait. Hasil penelitian menunjukan bahwa untuk pengendalian pencemaran Teluk Jakarta dibutuhkan lima langkah pengendalian sedangkan penanganan kematian massal ikan terdiri atas dua tahapan yang harus dilakukan oleh instansi terkait secara komperhensif dan terintegrasi.
\end{abstract}

Kata kunci: Mitigasi, Penanganan, Bencana Lingkungan, Teluk Jakarta, Kematian Massal Ikan.

\section{ABSTRACT}

The Jakarta Bay coastal waters are quite vulnerable to receiving heavy load of pollutants in the form of domestic, organic, industrial, heavy metal and oil spills which increase from time to time with a tendency to accumulate and settle at the bottom of the waters. The mass death event of fish in Jakarta Bay waters is a phenomenon that occurs as a result of changes in the quality of the aquatic environment. This change can occur physically or chemically. This research will try to describe the phenomenon of mass mortality in fish which is a recurring event that has lasted more than three decades in the Jakarta Bay. The aim is to provide recommendations on mitigation and adaptation as a strategic step in controlling environmental pollution as well as more comprehensive and appropriate handling of mass fish deaths in the Jakarta Bay. The method used in research is literature study and cooperative meetings between related agencies. The results showed that to control the pollution of Jakarta Bay five steps are needed while the handling of mass mortality of fish consists of two stages that must be carried out by related agencies in a comprehensive and integrated manner.

Keywords: Mitigation, handling, Natural Disaster, Jakarta Bay Coastal Waters, Fish Bulk Death. 


\section{PENDAHULUAN}

Pesisir Teluk Jakarta terletak di pantai Utara Jakarta dibatasi oleh garis bujur $106^{\circ} 33^{\prime} 00^{\prime \prime} \mathrm{BT}$ hingga $107^{\circ}$ $03^{\prime} 00^{\prime \prime} \mathrm{BT}$ dan garis lintang $5^{\circ} 48^{\prime} 30^{\prime \prime} \mathrm{LS}$ hingga $6^{\circ}$ 10'30" LS yang membentang dari Tanjung Kait di bagian Barat hingga Tanjung Karawang di bagian Timur dengan panjang pantai $\pm 89 \mathrm{Km}$. Panjang garis yang menghubungkan kedua Tanjung tersebut melalui Pulau Air Besar dan Pulau Damar adalah sekitar 21 mil laut. Secara administratif, perairan laut Jakarta berbatasan dengan Kabupaten Bekasi di sebelah timur dan Kabupaten Tangerang di sebelah barat (Nelwan et al., 2004; Hartati et al., 2014).

Wilayah perairan Teluk Jakarta secara ekologi merupakan wilayah perairan yang berfungsi sebagai tempat mencari makan (feeding ground), pemijahan (spawning ground) dan pengasuhan/pembesaran (nursery ground) dari beberapa jenis ikan ekonomis penting diantaranya ikan kembung, baronang, gulamah, tembang, udang dan rajungan (Nuraini et al., 2009; Nastiti et al., 2012; Suwarso et al., 2015, Wagiyo \& Hartati, 2006). Selain itu meroplankton di Teluk Jakarta yang teridentifikasi pada tahun 2009 dan 2010 terdiri atas 4 kelompok (ikan, telur, udang dan kepiting). Komposisi meroplankton di Teluk Jakarta tahun 2009 didominasi oleh larva udang sebesar 56,17- 90,40\% dan tahun 2010 sebesar 72,1-75,5 \%. Kelimpahan larva udang tahun 2014 lebih rendah dibanding tahun 2009-2010 (Suhenda, 2008; Nastiti \& Hartati, 2013; Nastiti et al., 2016). Hal ini diduga berhubungan dengan semakin terdegradasinya lingkungan perairan saat ini, baik kondisi ekosistem mangrove maupun kondisi hidrologi (Nastiti \& Hartati, 2013).

Morfolgi Teluk Jakarta yang berbentuk cekungan secara langsung menjadikan wilayah perairan tersebut semi tertutup. Hal ini mengakibatkan wilayah perairan Teluk Jakarta cukup rentan untuk menerima beban berat bahan pencemar baik berupa limbah organik dan anorganik (domestik dan industri) dari tiga belas aliran sungai yang bermuara ke Teluk Jakarta yang meningkat dari waktu ke waktu dengan kecenderungan terakumulasi dan mengendap di dasar perairan (Putranto, 2001; Yonvitner \& Imran, 2006; Sanusi et al., 2005; Ahmad, 2012; Irman et al., 2012; Dwikartika et al., 2015; Suryani 2015; Kim et al., 2016; Siregar et al., 2016; Marcinek, 2017). Suryani (2015) menyebutkan bahwa, air limbah domestik memberikan kontribusi pencemaran air sekitar $75 \%$, air limbah perkantoran dan daerah komersial 15\%, dan air limbah industry $10 \%$. Masalah pencemaran limbah ini lebih diperburuk lagi akibat berkembangnya lokasi permukiman di daerah penyangga Jakarta yang tanpa dilengkapi dengan fasilitas pengolah air limbah sehingga badan-badan sungai di wilayah DKI Jakarta menjadi tempat pembuangannya (Sachoemar et al., 2007).

Pencemaran ini dapat dikatakan sebagai bencana lingkungan karena telah mengakibatkan kematian massal ikan yang terjadi hampir setiap tahun. Jenisjenis ikan yang mati secara massal di Teluk Jakarta merupakan jenis ikan ekonomis penting yang dimanfaatkan oleh masyarakat pesisir Jakarta dan sekitarnya (Hartati et al., 2014; Suryani, 2015). Fakta menunjukan bahwa kasus kematian massal ikan telah menyebabkan kerugian ekonomi bagi nelayan, secara langsung mengganggu estetika laut di kawasan Ancol yang merupakan kawasan wisata pantai dan secara tidak langsung dapat menyebabkan gangguan kesehatan masyarakat baik dalam jangka pendek maupun jangka panjang.

Fenomena kematian massal ikan di Teluk Jakarta selama ini masih dianggap sebagai suatu kejadian insidentil sehingga belum mendapat perhatian yang komperhensif dan intensif dari para stakeholder. Selain itu, upaya pengendalian pencemaran dan penanganan kematian massal ikan yang dilakukan oleh para stakeholder juga belum terintegrasi secara baik. Tulisan ini bertujuan untuk memberikan rekomendasi tentang mitigasi dan adaptasi sebagai langkah strategis dalam pengendalian pencemaran lingkungan sekaligus penanganan yang lebih komperhensif dan tepat terhadap peristiwa kematian massal ikan di Teluk Jakarta.

\section{BAHAN DAN METODE}

Metode penelitian yang digunakan dalam penelitian ini adalah studi literatur dan pertemuan kooperatif antar instansi. Instansi yang terlibat dalam pertemuan ini adalah Pusat Riset Perikanan, Badan Riset dan Sumber Daya Manusia, Kementerian Kelautan dan Perikanan, Dinas Lingkungan Hidup Provinsi DKI Jakarta, Dinas Ketahanan Pangan Kelautan dan Pertanian Provinsi DKI Jakarta, dan PT. Pembangunan Jaya Ancol Tbk. Studi literatur dilakukan untuk mengumpulkan informasi terkait seluruh aktifitas yang berlangsung pada wilayah Teluk Jakarta dan/atau sekitarnya sekaligus informasi dampak yang mungkin timbul dari aktifitas tersebut baik secara ekologi, sosial ekonomi maupun kesehatan. Selanjutnya, dilakukan pertemuan kooperatif antar instansi untuk memperoleh detail 
fenomena dan tindakan pengendalian pencemaran yang telah dilakukan sebelumnya di Teluk Jakarta sekaligus, merumuskan alur penanganan pasca kematian massal ikan di Teluk Jakarta.

\section{HASIL DAN PEMBAHASAN}

\section{Pola Pencemaran di Teluk Jakarta}

Pencemaran di Teluk Jakarta telah menjadi isu sejak lama. Pada tahun 1974 dampak dari pencemaran ini mengakibatkan ledakan populasi alga yang disebut red tide (Nelwan et al., 2004). Salah satu akibat yang memberikan dampak yang signifikan yaitu terjadinya kematian massal ikan. Kematian massal ikan di Teluk Jakarta merupakan kejadian berulang yang sudah berlangsung lebih dari tiga dasawarsa (Hartati et al., 2014). Peristiwa kematian masal ikan sebagian besar terjadi pada awal musim hujan dengan intensitas curah hujan yang tinggi. Intensitas hujan yang tinggi meningkatkan volume dan aliran air tawar dari sungai yang masuk ke Teluk Jakarta dan membawa berbagai material limbah organik dan anorganik (Kim et al., 2016; Marcinek, 2017; Santoso, 2005). Di sisi lain, di wilayah perairan yang dangkal, derasnya arus dan besarnya debit air sungai bisa menjadi salah satu penyebab teraduknya lapisan dasar yang kemudian terangkat ke kolom air (upwelling) (Hartati,2014).

Upwelling menimbulkan dua kemungkinan yang bisa terjadi. Pertama, apabila limbah yang terangkat adalah limbah beracun, maka akan langsung mematikan ikan secara masal (Jalius, 2008; Sachoemar \& Wahyono, 2007). Kemungkinan kedua, bila limbah tersebut mengandung nutrient khususnya phsophat dan nitrat, maka akan berpengaruh terhadap peningkatan produktifitas fitoplaknton (blooming). Peningkatan populasi fitoplankton yang sangat tinggi dan cepat akan menyebabkan penurunan kandungan oksigen terlarut dan mengakibatkan kematian masal ikan (Masayu et al., 2016; Nastiti et al., 2016).

Pada 2001, kematian massal ikan di Teluk Jakarta disebabkan oleh bahan pencemar limbah kimia, yang diduga dibuang oleh pabrik-pabrik pengawetan kayu di sekitar Marunda dan Kalibaru. Pada 2004 dan 2005, penyebab terjadinya kematian massal ikan di Teluk Jakarta adalah akibat blooming dari fitoplankton sehingga terjadi penurunan oksigen yang menyebabkan ikan-ikan mati kekurangan oksigen (Nelwan et al., 2004). Dalam lima tahun terakhir peristiwa ini kembali terjadi secara beruntun yaitu pada 2013, 2014, dan 2015 yang menjadi sumber pencemarnya adalah bahan pencemar organik dan anorganik (Hartati et al., 2014; Kim et al., 2016; Siregar et al., 2016; Masayu et al., 2016; Marcinek, 2017).

Bahan pencemar organik yang terdeteksi mencemari wilayah perairan Teluk Jakarta adalah terdiri atas unsur phsopat dan nitrat (Hartati \& Awwaluddin, 2007; Damar, 2004; Hartati et al., 2014). Sedangkan untuk bahan pencemar dari bahan anorganik yang terdeteksi pada sampel air sungai dan air laut di sekitar Teluk Jakarta adalah berupa merkuri $(\mathrm{Hg})$, timbal $(\mathrm{Pb})$ dan cadmium $(\mathrm{Cd})$ yang termasuk dalam limbah B3 dengan level konsentrasi yang bervariasi dan sangat mengkhawatirkan bagi kesehatan manusia (Kim et al., 2016; Putranto, 2001; Siregar et al., 2016; Marcinek, 2017; Mustaruddin, 2013; Rochyatun, 2007; Wisaksono, 2000; Inswiasri et al., 1997). Indeks pencemaran di muara Teluk Jakarta berdasarkan lokasi tercemar menunjukan bahwa lokasi yang tercemar sedang sampai dengan tercemar berat sejak tahun 2010

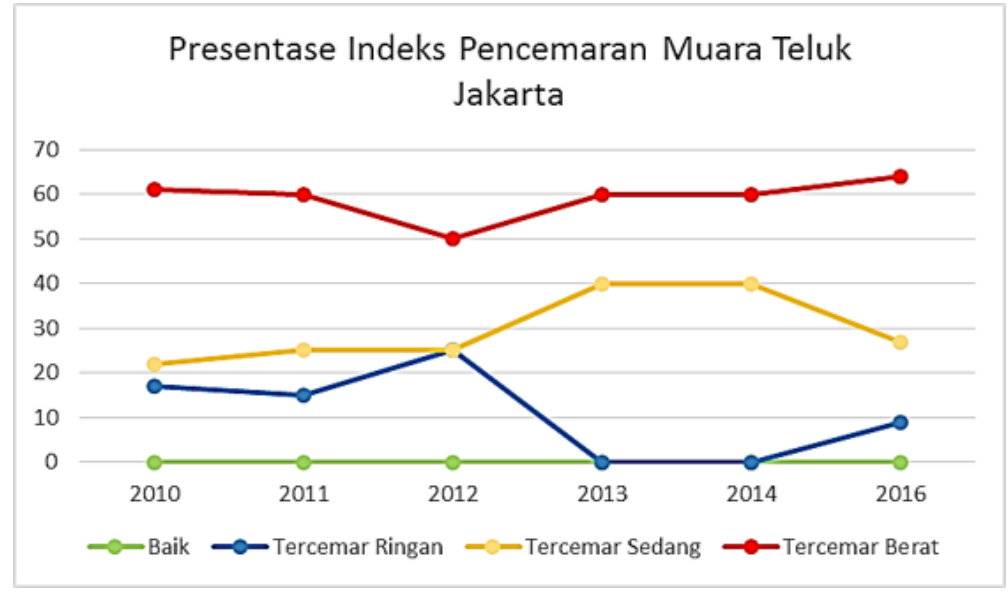

Gambar 1. Tren indeks presentase pencemaran di Teluk Jakarta. Sumber: Dinas Lingkungan Hidup DKI Jakarta (2017). 
sampai dengan 2016 terus mengalami peningkatan (Gambar 1).

\section{Dampak Sosial-Ekonomi}

Aktifitas manusia di sekitar Teluk Jakarta mempunyai intensitas yang tinggi. Pemanfaatan lahan perikanan di perairan Teluk Jakarta, secara intensif sudah lama dilakukan semenjak dasawarsa 1960-an (Panggabean \& Setadji, 2011). Secara umum diketahui bahwa Teluk Jakarta merupakan perairan yang memiliki potensi ekonomi penting salah satunya adalah perikanan tangkap yang terdapat di sekitar teluk. Tidak sedikit nelayan tradisional yang menggantungkan hidupnya dari sumberdaya ikan di perairan ini (Hartati et al., 2014; (Ilhamdi \& Yahya, 2016; Mulyadi, 2016).

Produksi atau hasil tangkapan ikan demersal, pelagis kecil dan rajungan dari sektor perikanan tangkap secara umum cenderung menurun sejak tahun 2006 dan hal ini diindikasikan sebagai akibat dari kualitas lingkungan yang terdegradasi dan banyaknya armada juga jenis alat tangkap yang beroperasi (Nauraini et al., 2009; Panggabean \& Setiadji, 2011). Hartati et al., (2014) mengemukakan bahwa, degradasi lingkungan perairan Teluk Jakarta ditandai dengan rendahnya biomassa ikan yaitu hanya sebesar 0,19 ton $/ \mathrm{km}^{2}$ sehingga menyebabkan jumlah total hasil tangkapan nelayan rendah $(0,74$ ton/hari). Hasil ikan tangkapan nelayan didominasi oleh jenis ikan rucah/trash fish yaitu ikan petek (Leioghnathus sp.) Ikan ekonomis yang tertangkap di Teluk Jakarta berukuran lebih kecil bila dibandingkan dengan ukuran standar FAO dan Fishbase. Modus ukuran panjang ikan kembung (Rastrelliger sp.) mengecil dua kali lipat dari ukuran standar (standar FAO: $34 \mathrm{~cm}$ ) dan ikan petek mengecil tiga kali lipat dari ukuran standar (standar FAO: $18 \mathrm{~cm}$ ). Selain itu, degradasi sumberdaya ikan juga ditandai dengan adanya kerusakan jaringan insang dan hati pada ikan beronang (Siganus sp.), kerang hijau (Perna viridis) dan rajungan (Portunus sp.).

Menurut Ramadhan et al. (2016), jika perairan Teluk Jakarta mengalami gangguan maka jumlah nelayan di wilayah Teluk Jakarta yang mencapai 6.268 nelayan tetap dan 17.760 nelayan pendatang akan mengalami kerugian ekonomi yang sangat tinggi. Potensi kerugian nelayan penangkap ikan sebesar Rp. 527.939.667.305 per tahun bila aktivitas penangkapan ikan tidak lagi dapat dilakukan. Sedangkan, bila nelayan masih dapat melakukan penangkapan ikan di sekitar Teluk Jakarta, akan tetapi kehilangan sebagian wilayah penangkapan ikan (Fishing ground), potensi kerugian yang diderita oleh nelayan dapat mencapai Rp. 94.714.228.734 per tahun.

Pencemaran Teluk Jakarta juga berdampak bagi sektor perikanan budidaya. Peningkatan bahan pencemar organik (phsophat dan nitrat) di kolom perairan Teluk Jakarta mengakibatkan perairan ini menjadi subur (Hartati \& Awwaluddin, 2007; Damar, 2004; Hartati et al., 2014). Tingginya kesuburan perairan Teluk Jakarta juga menyebabkan tingginya sumber makanan bagi beberapa organisme perairan khususnya kerang hijau. Hal ini menyebabkan berkembangnya usaha budidaya kerang hijau di kawasan ini. Namun, dengan sifat hidupnya yang filter feeder menyebabkan kerang hijau memakan seluruh bahan tersuspensi termasuk bahan organik yang telah terkontaminasi oleh bahan pencemar lainnya, seperti berbagai jenis logam berat, sehingga logam berat yang berbahaya tersebut memiliki peluang untuk terakumulasi di dalam tubuh kerang hijau.

Kondisi demikian jika terus dibiarkan maka akan membuat aktivitas budidaya kerang hijau menjadi terhentisehinggasecaralangsungakanberdampaksecara sosial-ekonomi. Secara ekonomi akan mengakibatkan kerugian finansial bagi aktivitas perikanan (pemasaran/ penjualan) kerang hijau. Sedangkan, secara sosial akan menimbulkan peningkatan angka pengangguran.

Aktivitas budidaya kerang hijau yang merupakan usaha padat karya, melibatkan dua kategori tenaga kerja yang dipakai yaitu tenaga kerja untuk konstruksi rakit dan tenaga kerja panen (buruh panen) termasuk kategori alokasi biaya langsung. Sedangkan kategori biaya tidak langsung, melibatkan juga dua kategori tenaga kerja yaitu, buruh rebus dan buruh kupas (Hartanto, 2007). Jumlah tenaga kerja dan proporsi upah per kategori tenaga kerja dapat dilihat pada tabel 1. Selanjutnya berdasarkan hasil analisis Hartanto (2007), diketahui bahwa nilai ekonomi total dari usaha budidaya kerang hijau di Teluk Jakarta adalah sebesar Rp. 21.485.833,--

Jika kondisi ini tidak segera ditangani secara tepat maka, tidak hanya menurunkan tingkat pendapatan nelayan, tetapi juga menjadikan nelayan jatuh ke jurang kemiskinan akibat hilangnya mata pencaharian (Panggabean \& Setiadji 2011; Mulyadi, 2016).

\section{Dampak Kesehatan}

Menurut Setiady et al. (1980), masyarakat teluk Jakarta telah terpapar oleh logam berat $\mathrm{Hg}$ namun, kandungan merkuri pada rambut dari penduduk yang disurvei di sepanjang Teluk Jakarta masih berada dalam kisaran normal. Hal ini pun sama dengan kandungan timbal (Pb) pada hasil perikanan lautdi di Teluk Jakarta. 
Tabel 1. Penggunaan tenaga kerja dan total upah pada usaha budidaya kerang hijau di Teluk Jakarta

\begin{tabular}{|c|c|c|}
\hline Kategori Tenaga Kerja & Jumlah Orang & Total Upah Per Tahun (Rp.) \\
\hline \multicolumn{3}{|c|}{ Tenaga kerja untuk konstruksi rakit (Biaya langsung) } \\
\hline a) Konstruksi rakit & 12 & $240.000,-$ \\
\hline Buruh panen & 6 & $1.076 .250,-$ \\
\hline \multicolumn{3}{|c|}{ Usaha perebusan kerang hijau (Biaya tidak langsung) } \\
\hline a) Buruh rebus & 4 & $553.000,-$ \\
\hline Buruh kupas & 60 & $830.250,-$ \\
\hline TOTAL & 82 & 2.699.500,- \\
\hline
\end{tabular}

Wahyuningsih et al. (2015) mengemukanan bahwa, rata-rata kandungan logam $\mathrm{Pb}$ baik pada musim Timur dan musim Barat umumnya masih sangat rendah $(<0,042 \mathrm{mg} / \mathrm{kg})$ jauh di bawah ambang batas yang ditetapkan SNI. Sedangkan kandungan Cd ditemukan pada seluruh jenis sampel hasil perikanan dan yang tertinggi pada kerang darah $(0,747 \mathrm{mg} / \mathrm{kg})$. Keadaan tersebut menunjukkan bahwa kadar $\mathrm{Pb}$ dan $\mathrm{Cd}$ hasil perikanan laut dari Teluk Jakarta masih berada di bawah ambang batas yang titetapkan SNI (2009) sebanyak $1 \mathrm{mg} / \mathrm{kg}$, kecuali ikan yang telah melebihi ambang batas yang ditentukan, di mana kandungan $\mathrm{Cd}$ pada bawal hitam $(0,207 \mathrm{mg} / \mathrm{kg})$ dan ikan kembung $(0,110 \mathrm{mg} / \mathrm{kg})$ berada di atas ambang batas yang ditentukan SNI (2009), ISIRI dan WHO. Konsentrasi logam-logam berat ini akan semakin tinggi seiring dengan berlangsungnya musim kemarau (Inswiasri et al., 1997).

Jenis-jenis ikan ekonomis penting yang teridentifikasi pada saat kematian massal di Teluk Jakarta pada tahun 2015 dan 2016 dapat dilihat pada Tabel 2. Tabel ini juga menunjukan bahwa pada tubuh ikan yang mengalami kematian massal mengandung beberapa jenis logam berat diantara merkuri $(\mathrm{Hg})$ dan timbal $\mathrm{Pb}$ ) yang konsentrasinya cukup tinggi dan berbahaya jika dikonsumsi oleh manusia.

Menurut Jalius et al. (2008) konsentrasi merkuri pada daging kerang hijau (Perna viridis) adalah sebesar 0,0222 $\pm 0,0264$ pbb. Berdasarkan Kompas, (2017b), tingkat pencemaran merkuri pada daging kerang hijau terus mengalami peningkatan dan telah melampaui ambang batas baku mutu yaitu telah mencapai 27,86$45,41 \mathrm{mg} / \mathrm{kg}$. Konsentrasi merkuri juga ditemukan pada daging dan hati empat spesies ikan pari (Himantura walga, Neotrygon kuhlii, Himantura gerardi, dan Himantura uarnacoides) yang merupakan hasil tangkapan di Teluk Jakarta. Konsentrasi merkuri pada daging dan hati keempat spesien ikan pari ini mencapai 0,633 mg/kg (Kompas, 2017a). Jika melihat konsentrasi $\mathrm{Hg}$ yang meningkat setiap tahunnya maka sudah seyogyanya tingkat konsentrasi merkuri di perairan Teluk Jakarta harus diwaspadai oleh semua lapisan

Tabel 2. Jenis-jenis ikan ekonomis penting yang mati massal di Teluk Jakarta

\begin{tabular}{llllll}
\hline No. & Jenis Ikan & $\mathbf{2 0 1 5}$ & \multicolumn{2}{c}{$\mathbf{2 0 1 6}$} \\
& & Hg (mg/kg) & Pb (mg/kg) & Hg (mg/kg) & Pb (mg/kg) \\
\hline 1 & Kakap & 0,025 & ND & ND & ND \\
2 & Kerapu & 0,044 & ND & 0,009 & 0,019 \\
3 & Baronang & 0,018 & ND & ND & ND \\
4 & Kwe & ND & ND & 0,004 & 0,516 \\
5 & Tembang & ND & ND & 0,009 & 0,977 \\
6 & Belanak & 0,006 & ND & 0,009 & 0,412 \\
7 & Bandeng & 0,020 & ND & 0,006 & 0,611 \\
8 & Ketang-Ketang & 0,020 & 0,014 & ND & ND \\
9 & Sembilang & 0,084 & 0,016 & ND & ND \\
10 & Buntal & ND & ND & 0,009 & 0,989 \\
\hline \multicolumn{2}{l}{ Sumber: Dinas Ketahanan Pangan Kelautan Pertanian DKI Jakarta, 2017. ND (Not Detected). }
\end{tabular}


masyarakat karena konsumsi berlebih organisme laut yang mengandung merkuri akan mengakibatkan akumulasi merkuri dalam tubuh.

Merkuri (Hg) merupakan suatu polutan bagi lingkungan jika toksisitasnya tinggi, bahkan merkuri pada konsentrasi yang rendah mampu untuk bioakumulasi dalam organisme dan biomagnify dalam rantai makanan (Porto et al., 2005; UNEP, 2013). Di lingkungan, bentuk anorganik ( $\mathrm{Hg} 0$ dan $\mathrm{Hg}$ (II)) mudah diubah oleh spesies organik (Bisinoti \& Jardim, 2003; Voegborlo \& Akagi, 2007). Di antara transformasi utama adalah pembentukan methylmercury $(\mathrm{MeHg})$ (Blum et al., 2013). Jenis unsur kimia ini dapat masuk ke dalam rantai makanan perairan dan konsentrasinya sangat tinggi dalam jaringan ikan, $\mathrm{MeHg}$ menyumbang $80 \%$ sampai $95 \%$ dari total merkuri (Afonso et al., 2008; Blum et al., 2013).

Merkuri dapat terdistribusi secara bebas dan luas melalui limbah padat dan cair yang berasal dari rumah tangga dan beberapa kegiatan industri. (Bose-O'Reilly et al., 2016) juga dari hasil ekstraksi emas pada penambangan emas (Steckling et al., 2017; Ha et al., 2017) yang masuk ke badan air sungai (Subanri, 2008) ataupun melalui air tanah (Sachoemar \& Wahyono, 2007; Putranto, 2011). Merkury yang masuk ke badan perairan sungai sebagian akan terakumulasi dengan organisme yang hidup didalamnya dan sebagian lagi akan terbawa sampai ke eksositem pesisir dan laut kemudian tersuspensi ke sedimen di dasar perairan laut (Sinder et al., 2016), juga akan terakumulasi dengan organisme perairan laut lewat rantai makanan (Costa et al., 2016).

Merkuri bersifat toksik bagi kesehatan manusia dan salah satu jalur utama paparan adalah melalui konsumsi yang terkontaminasi ikan dan kerang (Costa et al., 2016). Organisasi Kesehatan Dunia (WHO) mengasumsikan bahwa makanan dengan konsentrasi merkuri $0,5 \mathrm{mg} \mathrm{kg}^{-1}$ (berat basah) atau lebih, tidak layak untuk dikonsumsi oleh manusia (WHO, 2005). Jika kerang hijau yang telah terkontaminasi logam berat dikonsumsi oleh mamusia maka akan memberikan efek negatif bagi kesehatan. Methylmercury ( $\mathrm{MeHg}$ ) yang tergolong kelompok merkuri organik dan termasuk bentuk alkil rantai pendek dengan waktu paruh dalam darah manusia hanya sekitar 50 hari merupakan racun yang sangat potensial menyerang sistem saraf (neurotoksin) sehingga menimbulkan degenerasi neuron di korteks cerebri dan cerebellum serta mengakibatkan parestesi distal, ataksia, disartria, tuli, penyempitan lapang pandang, kerusakan permanen pada otak, hati dan ginjal (Roger et al., 1984). Carrier et al., (2001) mengemukakan bahwa, MeHg dapat dengan mudah diangkut secara bebas ke seluruh tubuh termasuk di seluruh membran pembuluh darah dan otak bahkan termasuk di seluruh plasenta, di mana $\mathrm{MeHg}$ dapat langsung diserap oleh janin yang sedang berkembang dan berakumulasi dalam fetus yang mengakibatkan cerebral palsy dan kematian dalam kandungan.

\section{Pengendalian Pencemaran Teluk Jakarta}

Upaya untuk mengoptimalkan daya dukung perairan Teluk Jakarta terhadap kehidupan ikan, sebaiknya sanitasi lingkungan harus dilakukan secara menyeluruh baik daerah hilir maupun daerah hulu Wagiyo \& Hartati, (2006). Pengendalian pencemaran Teluk Jakarta yang telah dilakukan oleh pemerintah DKI Jakarta diantaranya adalah; 1) menormalisasi sungaisungai yang mengalir ke Jakarta, 2) memperbaiki dan memperbarui kawasan Teluk Jakarta, dan 3) Reklamasi Teluk Jakarta. Dari segi kebijakan, upaya pengendalaian pencemaran Teluk Jakarta telah diperkuat juga oleh berbagai peraturan, baik dari level peraturan Gubernur (Pergub) maupun level Undang-Undang yang ditetapkan oleh lembaga legislatif Negara. Berikut adalah beberapa perangkat peraturan yang ditetapkan dalam rangka mencegah dan/atau mengendalikan terjadinya pencemaran Teluk Jakarta:

- Peraturan Gubernur DKI Jakarta No. 30 Tahun 1999 tentang Perizinan Pembuangan Limbah Cair di DKI Jakarta

- Peraturan Gubernur No. 122 Tahun 2005 tentang Pengelolaan Air Limbah Domestik di DKI Jakarta,

- UU. No. 24 tahun 2007 tentang Penanggulangan Bencana

- UU. No. 18 Tahun 2008 tentang Pengelolaan Sampah

- UU. No. 32 Tahun 2009 tentang Perlindungan dan Pengelolaan Lingkungan Hidup

- Peraturan Gubernur No. 69 Tahun 2013 tentang Baku Mutu Air Limbah bagi Kegiatan dan/atau Usaha.

- Peraturan Pemerintah No. 101 Tahun 2014 tentang Pengelolaan Limbah Bahan Berbahaya dan Beracun

Meskipun telah ditetapkan berbagai perangkat peraturan terkait dengan pencegahan dan/atau pengendalian pencemaran Teluk Jakarta namun, dalam kenyataannya peristiwa ini masih tetap berlangsung sehingga berdampak bagi kematian masal ikan. Peristiwa kematian masal ikan di Teluk Jakarta dapat dicegah dan ditangani melalui kegiatan mitigasi (pencegahan/ pengurangan dampak) dan adaptasi (penyesuaian). 
Kegiatan mitigasi dan adaptasi pada lingkungan perairan Teluk Jakarta dapat dilakukan melalui berbagai inovasi teknologi dan manajemen wilayah pesisir yang tersistematis. Wilayah pesisir yang didukung oleh tiga eksosistem utamanya yaitu ekosistem mangrove, lamun dan terumbu karang, secara alami lebih resisten dan berperan dalam mencegah dan/atau mengurangi probabilitas faktor penyebab fenomena ini.

\section{Penanganan Pasca Kematian Massal Ikan}

Penanganan kematian masal ikan di Teluk Jakarta harus dilakukan sesegera mungkin sehingga dapat meminimalisir dampak kerugian yang ditimbulkan. Penanganan kematian ikan harus dilakukan secara komprehensif dimulai dari membersihkan bangkai ikan sampai dengan pelaksanaan monitoring kualitas air yang dilakukan secara terpadu. Hal ini pun harus dilakukan secara terintegrasi oleh seluruh stakeholder terkait, baik dari pihak pemerintah, swasta, LSM dan didukung oleh seluruh lapiasan masyarakat.

Tahapan yang harus dilakukan pasca kematian massal ikan adalah sebagai berikut:

- Mengumpulkan dan mengangkut bangkai ikan yang sudah mati sesegera mungkin ke lahan yang sudah ditentukan. Kegiatan ini di bawah koordinasi Dinas Lingkungan Hidup DKI Jakarta yang melibatkan Lembaga Swadaya Masyarakat dan masyarakat pesisir Teluk Jakarta.

- Monitoring kualitas air di wilayah perairan tempat kejadian kematian massal ikan. Kegiatan ini di bawah koordinasi bersama antara Dinas Lingkungan Hidup DKI Jakarta, Dinas Ketahanan Pangan, Kelautan dan Pertanian DKI Jakarta, Badan Riset dan Sumber Daya Manusia Kelautan dan Perikanan (BRSDM KP), dan Pusat Penelitian Oseanografi LIPI (P2O LIPI).

Diagram alur pengendalian pencemaran dan penanganan kematian massal ikan di Teluk Jakarta digambarkan pada gambar 2. Panah besar menunjukan hubungan antara sumber pencemaran dengan upaya pengendaliannya dan hubungan antara pencemaran dan kematian massal ikan dengan upaya penangannya; Panah tebal menunjukan aliran intervensi; Panah tipis menunjukan hubungan antara instansi dengan tannggung jawab/wewenang; Kotak menunjukan variabel; Garis putus-putus menunjukan hubungan koordinasi antara instansi.

\section{KESIMPULAN DAN SARAN}

Mitigasi pencemaran Teluk Jakarta dan dampak kematian massal ikan membutuhkan (1) fokus pada keadilan dan kesinambungan pembangunan pada berbagai tingkatan; (2) bekerja sama secara konstruktif antara semua stakeholder dan semua lapisan masyarakat pada tingkat lokal (DKI Jakarta) dan regional (melibatkan Kota/Kabupaten di sekitar Jakarta; Bogor, Tangerang, Bekasi, Depok, Puncak dan Cianjur); dan, (3) regulasi yang jelas dan tegas serta fokus dalam mengatur seluruh kegiatan yang dapat menghasilkan limbah baik domestik maupu industri. Adaptasi merupakan suatu tindakan yang diambil untuk mengurangi kerentanan dan meningkatkan resiliensi. Penekanan pada adaptasi diperlukan karena dampak kematian masal ikan begitu mengkhawatirkan. Pada kontes lokal (masyarakat pesisir Teluk Jakarta) adaptasi di $\neg$ perlukan segera untuk mengurangi dampak dari kematian masal ikan.

Rekomendasi yang terkait dengan mitigasi pencemaran Teluk Jakarta untuk mengantisipasi dan meminimalkan kasus-kasus kematian massal ikan adalah sebagai berikut:

1. Pemerintah Daerah melakukan: (1) melalui Dinas Lingkungan Hidup DKI Jakarta segera melakukan pembangunan Instalasi Pengolahan Air Limbah IPAL komunal pada 13 lokasi yang disesuaikan dengan 13 aliran sungai yang masuk ke Teluk Jakarta; (2) melalui Badan Perencanaan dan Pembangunan Daerah (BAPPEDA) DKI Jakarta wajib melakukan penyempurnaan tata ruang wilayah dan pesisir perairan Teluk Jakarta; dan (3) Pemerintah Daerah di wilayah Jabodetabekpunjur wajib melakukan Program kali bersih (Prokasi) pada 13 daerah aliran sungai yang bermuara di Teluk Jakarta.

2. Kementerian Kelautan dan Perikanan mengkoordinasikan pengelolaan perikanan di wilayah Teluk Jakarta dengan melakukan analisis daya tampung wilayah teluk dan sekaligus melakukan pemetaan lokasi yang terindikasi berpeluang menerima beban cemar yang akan berdampak pada kematian massal ikan.

3. Saat terjadi kasus kematian massal pada ikan, pemerintah daerah perlu melakukan tindakan penanganan untuk mencegah kondisi perairan menjadi lebih buruk dengan langkah-langkah: (i) membentuk Satuan Tugas penanganan kematian massal ikan yang terdiri dari unsur Dinas Lingkungan Hidup DKI Jakarta, Dinas Ketahanan Pangan Kelautan dan Pertanian DKI Jakarta, Pusat Riset Perikanan BRSDMKP, Pusat Penelitian Oseanografi LIPI, kelompok pengawas masyarakat (pokwasmas), Polisi Air, dan lembaga terkait lainnya. Satgas penanganan kematian 


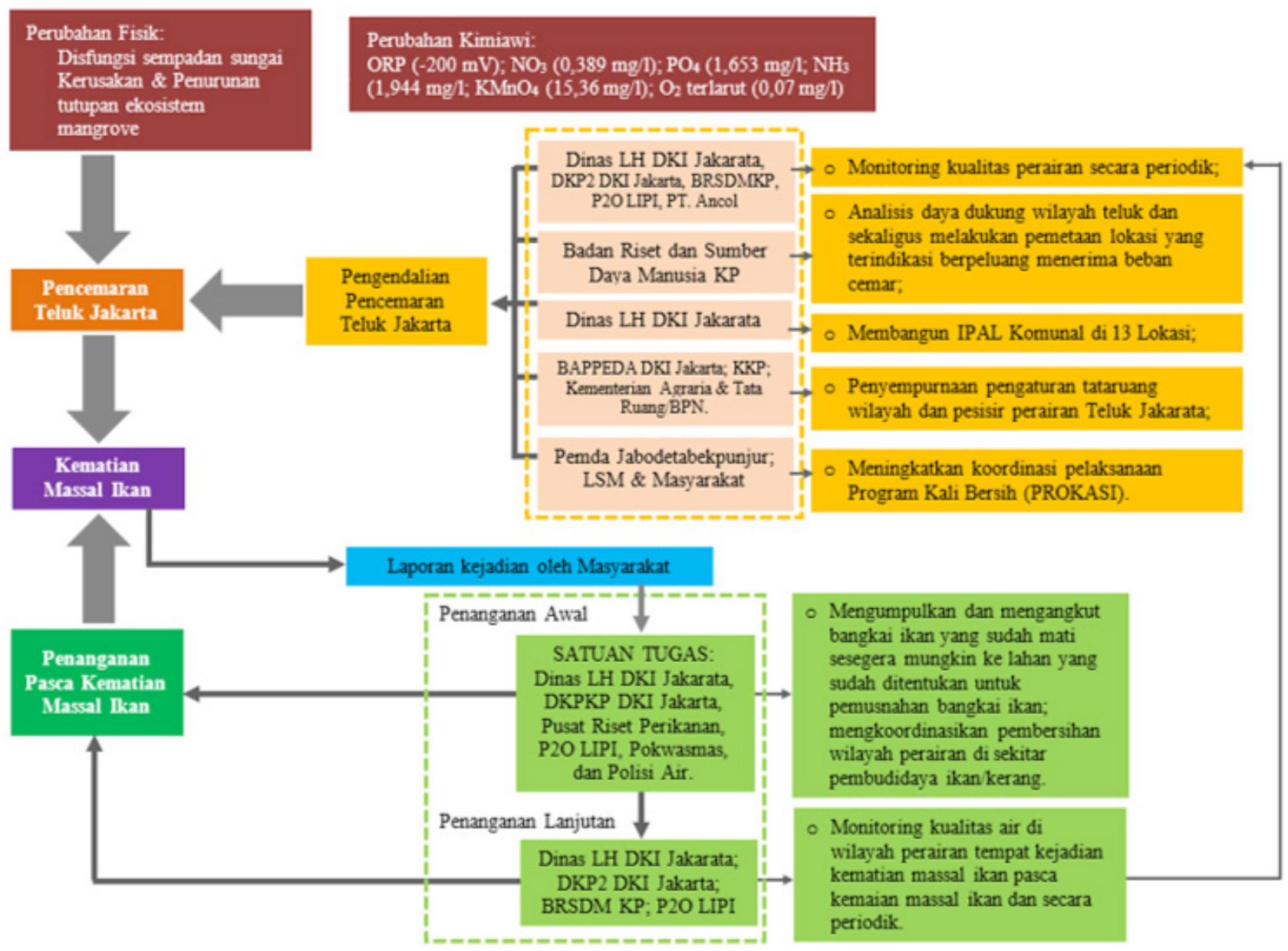

Gambar 2. Alur Pengendalian Pencemaran dan Penanganan Kematian Massal Ikan di Teluk Jakarta.

masal ikan bertugas untuk mengangkat ikan yang sudah mati sesegera mungkin, untuk menghindari terjadinya pembusukan dari ikan yang mati di perairan, mobilisasi pengangkutan ikan mati ke darat, mendorong upaya pemanfaatan ikan mati layak konsumsi/pakan ternak atau mengkoordinir penguburan bangkai ikan yang sudah membusuk; (ii) menyediakan lahan untuk pemusnahan bangkai ikan; (iii) mengkoordinasikan pembudidaya ikan untuk membersihkan perairan dan alat (jaring dan karamba) untuk menghindari penyebaran bakteri, parasit atau jamur yang dapat menyebabkan penyakit akibat bangkai ikan yang membusuk; dan (iv) melalui instansi/dinas yang menangani pengelolaan lingkungan hidup daerah, melakukan monitoring kualitas air secara periodik dan pasca kematian ikan.

\section{UCAPAN TERIMA KASIH}

Ucapan terima kasih penulis sampaikan kepada Kepala Pusat Riset Perikanan BRSDM-KP yang telah mendanai pertemuan kooperatif antar instansi dengan DIPA tahun 2017. Adapun analisis lanjutan dan mendalam dilakukan sepanjang 2018-2019. Juga kepada seluruh pihak yang telah membantu selama pelaksanaan pertemuan dan penyelesaian tulisan ini.

\section{DAFTAR PUSTAKA}

[Ahmad Fasmi. (2012). Kandungan senyawa polisiklik aromatic hidrokarbon (PAH) di Teluk Jakarta. Ilmu Kelautan. 17(4): 199-208.

Alfonso, C., Lourenço, H. M., Pereira, C., Martins, M. L., Carvalho, M. L., Castro, M., et al. (2008). Total and organic mercury, selenium and a-tocopherol in some deep-water species. Journal of the Science of Food and Agriculture, $88,2543-2550$.

Bisinoti, M. C., \& Jardim, W. F. (2003). Production of organic mercury from $\mathrm{Hg} 0$ : experiments using microcosms. Journal of the Brazilian Chemical Society, 14, 244-248. 
Blum, J.D., Popp, B.N., Drazen, J.C., Choy, A., \& Johnson, M.W. (2013). Methylmercury production below the mixed layer in the North Pacific Ocean. Nature Geoscience, 6, 879-884.

Bose-O'Reilly Stephan, Rudolf Schierl, Dennis Nowak, Uwe Siebert, Jossep Frederick William, Fradico Teorgi Owi, Yuyun IsmawatiIr. (2016). A preliminary study on health effects in villagers exposed to mercury in a small-scale artisanal gold mining area in Indonesia. Environmental Research. $\quad \mathrm{http}: / / \mathrm{dx}$. doi.org/10.1016/j. envres.2016.04.007

Carrier Gae'tan, Miche'le Bouchard, Robert C. Brunet, Myle'ne Caza. (2001). A Toxicokinetic Model for Predicting the Tissue Distribution and Elimination of Organic and Inorganic Mercury Following Exposure to Methyl Mercury in Animals and Humans. II. Application and Validation of the Model in Humans. Toxicology and Applied Pharmacology. 171(50-60). doi:10.1006/taap.2000.9113

Costa Fernanda do N., Maria Graças A. Korn, Geysa B. Brito, Stacy Ferlin, \& Anne H. Fostier. (2016). Preliminary results of mercury levels in raw and cooked seafood and their public health impact. Food Chemistry, 192. (837-841).

Damar, A. (2004). Teluk Jakarta, Tercemar sekaligus subur. http://www.kompas.com

Dinas Lingkungan Hidup Provinsi DKI Jakarta. (2017). Kualitas air muara dan Teluk Jakarta. Bahan persentasi pada rapat koordinasi dengan Pusat Riset Perikanan pada tanggal 23 November 2017.

Dinas Ketahanan Pangan Kelautan dan Pertanian Provinsi DKI Jakarta. (2017). Riwayat kejadian kematian massal ikan di Teluk Jakarta. Bahan persentasi pada rapat koordinasi dengan Pusat Riset Perikanan pada tanggal 23 November 2017.

Hartanto. (2007). Analisis biaya manfaat relokasi budidaya kerang hijau (Mytilus viridis) di Perairan Teluk Jakarta. Tesis: Institut Pertanian Bogor. Bogor.

Hartati Sri Turni \& Awwaluddin. (2007). Struktur komunitas makrozoobentos di perairan Teluk Jakarta. J. Lit. Perikan. Ind. 13(2): 105-124.

Hartati Sri Turni, Puspasari Reny, Triharyuni Setiya, Sulaiman Priyo Suharsono, Utama, Andria Ansri, Rahmadi Puji. (2014). Kajian perikanan dan lingkungan di Teluk Jakarta. Laporan akhir 2014, Pusat Penelitian Pengelolaan Perikanan dan Konservasi Sumber Daya Ikan, BALITBANG KP, KKP. p.92.

Ilhamdi Hari \& Mohammad Fadli Yahya. (2016). Pengamatan aspek operasional penangkapan alat cantrang di perairan Teluk Jakarta. BTL. 4 (1): 23-27.

Inswiasri, A. Tri Tugaswati, Agustina Lubis. (1997). Study on trace metal concentration in freshfish and shellfish from Jakarta Bay, 1995/1996. Buletin Peneliti Kesehatan. 25(1): 19-26.

Irman Firmansyah, Etty Rian, Rahmat Kurnia. (2012). Model pengendalian pencemaran laut untuk meningkatkan daya dukung lingkungan Teluk Jakarta. JPSL. 2(1): 22-28.

Jalius, Daniel Djoko Setiyanto, Komar Sumantadinata, Etty Riani, \& Yunizar Ernawati. (2008). Bioakumulasi logam berat dan pengaruhnya terhadap oogenesis kerang hijau (Perna viridis). J. Ris. Akuakultur. 3(1): 43-52.

Kim Ki-Hyun, Ehsanul Kabir, Shamin Ara Jahan. (2016). A review on the distribution of $\mathrm{Hg}$ in the environment and its human health impacts. Journal of Hazardous Materials 306, (376-385).

Kompas. (2017a). Pencemaran logam kian parah. https://www.pressreader.com/Indonesia/ kompas/20170711/281865823508146. November 2017. 21:10 WIB.

Kompas. (2017b). Polusi logam berat merisaukan. https://www.pressreader.com/Indonesia/ kompas/20170710/281840053702409. November 2017. 20:50 WIB.

Marcinek Jacel Marta, Jadwiga Albińska, Aleksandra Pawlaczyk, Małgorzata Iwona Szynkowska. (2017). The impact of demographic factors, behaviors and environmental exposure to mercury content in the hair of the population living in the region of Lodz (central Poland). 
Environmental Toxicology and Pharmacology, 55(196-201).

Marissa, D., Muslim., \& Makmur, M. (2015). Studi karbon organic di sedimen dengan ukuran butir pada perairan Teluk Jakarta. Jurnal Oseanografi - UNDIP. 4(4):718-722.

Masayu P. Rahmia Anwar, Sri Turni Hartati, \& Fayakun Satria. (2016). Kematian massal ikan dan sebaran parameter kualitas air di Teluk Jakarta. BAWAL, 8(2): 77-90.

Mulyadi Muhammad. (2016). Dampak negative reklamasi Teluk Jakarta. Info Singkat Kesejahteraan Sosial. Pusat Pengkajian, Pengelolaan Data dan Informasi Sekretariat Jenderal DPR RI. Vol. VIII(08).

Mustaruddin. (2013). Pola pencemaran $\mathrm{Hg}$ dan $\mathrm{Pb}$ pada fishing ground dan ikan yang tertangkap nelayan : Studi kasus di Teluk Jakarta. Jurnal Bumi Lestari. 13(2): 214-224.

Nastiti Adriani Sri, Bambang Sumiono, \& Achmad Fitriyanto. (2012). Distribusi spasial dan temporal juvenil udang dalam kaitannya dengan lingkungan perairan di Teluk Jakarta. J. Lit. Perikanan. Ind. 18 (3): 157-166.

Nastiti Adriani Sri, Masayu Rahmia Anwar Putri, \& Sri Turni Hartati. (2016). Hubungan antara kelimpahan meroplankton dengan kualitas perairan di Teluk Jakarta. BAWAL. 8(2): 91-100.

Nastiti Adriani Sri \& Sri Turni Hartati. (2013). Struktur komunitas plankton dan kondisi lingkungan perairan di Teluk Jakarta. BAWAL. 5(3): 131150.

Nuraini Siti, Prihatiningsih, \& Sri Turni Hartati. (2009). Parameter populasi dan selektivitas rajungan (Poftunus pelagicus Linnaeus) yang tertangkap dengan beberapa jenis alat tangkap di Teluk Jakarta. J. Lit. Perikan. lnd. 15(4): 287-295.

Nelwan Alfa, Haryadi Sigid, Setawati Mia, Bijaksanan Untung, Syafiuddin, Mamangkey Jefry J., Nasuion S. Husni, Lokollo Johanes, Mssi Kemal, Setyaningsih Iriani, Saragih Bernatal, Mailoa Meity. (2004). Pencemran perairan Teluk Jakara dan strategi penanggulangannya. Pengantar Falsafah Sains. S3. Sekolah Pasca
Sarjana IPB. Institut Pertanian Bogor.

Panggabean Anthony Sisco \& Setiadji Bram. (2011). Bentuk pertumbuhan karang daerah tertutup dan terbuka di perairan sekitar pulau pamegaran, Teluk Jakarta. BAWAL. 3(4): 255-260.

Putranto Thomas Triadi. (2011). Pencemaran logam berat merkuri $(\mathrm{Hg})$ pada air tanah. TEKNIK. 32(1): 62-76. ISSN 0852-1697.

Ramadhan Andrian, Maulana Firdaus, Rizky Aprilian Wijaya, \& Irwan Muliawan. (2016). Estimasi kerugian nelayan dan pembudidaya ikan akibat reklamasi di Teluk Jakarta. J. Sosek KP. 11(1) : $1-11$.

Rochyatun Endang \& Abdul Rozak. (2007). Pemantauan kadar logam berat dalam sedimen di perairan Teluk Jakarta. MAKARA SAINS. Vol. 11(1): 28-26.

Roger A. R, Lawrence H. K. (1984). Water analysis: Inorganic spesies. 2nd Ed. Orlando. Florida. Academic Press.

Sachoemar Suhendar. I., \& Wahjono Heru Dwi. (2007). Kondisi pencemaran lingkungan perairan di Teluk Jakarta. JAI, 3(1): 1-14.

Sanusi Harpasis S., Alan F. Koropian, Haeruddin dan Andis K. Nugaraha. (2005). Pemodelan pola arus dan sebaran konsentrasi tembaga $(\mathrm{Cu})$ terlarut di Jakarta. Ilmu Kelautan. 10(3): 165-168.

Santoso Arif Dwi. (2005). Pemantauan hidrografi dan kualitas air di Teluk Hurun Lampung dan Teluk Jakarta. J. Tek. Ling P3TL. 6(3): 433-437.

Satmoko Wisaksono. (2000). Ancaman di balik hasil laut di perairan Teluk Jakarta terhadap kesehatan masyarakat. Media Litbang Kesehatan. 9(4): 1617.

Setiady I. F., Sumengen, A. Karyadi, Iwan Darmansyah, A. S. Santoso, Sri Soewasti Soesanto, Suparnadi Praptasuganda, Suryanti, Hari Hartoyo. (1980). Hasil survai keracunan merkuri pada penduduk di sekitar Teluk Jakarta. Buletin Penelitian Kesehatan, 9(1): 1-11.

Siregar Tuti Hartati, Priyanto Nandang, Putri Ajeng Kurniasi, Rachmawati Novalia, Triwibowo

JURNAL RISET JAKARTA, Vol. 12, No 2, NOVEMBER 2019, Hal. 77-88 
Radestya, Dskowitzky Larissa, Schwarzbauer Jan. (2006). Spatial distribution and seasonal variation of the trace hazardous element contamination in Jakarta Bay, Indonesia. Marine Pollution Bulletin 110: 634-646.

Suhenda Enda. (2008). Teknik pengambilan, identifikasi, dan penghitungan kelimpahan plankton di perairan Teluk Jakarta. BTL.7 (2): 51-55.

Sachoemar Suhendar I., \& Heru Dwi Wahjono. (2007). Kondisi pencemaran lingkungan perairan Teluk Jakarta. JAI. Vol. 3 (1): 1-14.

Suryani Anih Sri. (2015). Pencemaran di Teluk Jakarta. Info Singkat Kesejahteraan Sosial. Pusat Pengkajian, Pengelolaan Data dan Informasi Sekretariat Jenderal DPR RI. Vol. VII (24).

Suwarso, Tri Ernawati dan Tuti Hariati. (2015). Biologi reproduksi dan dugaan pemijahan ikan kembung (Rastrelliger brachysoma) di pantai Utara Jawa. BAWAL. 7 (1): 9-16.

United Nations Environment Programme - UNEP. (2013). Global Mercury Assessment 2013: Sources, Emissions, Releases, and Environmental Transport. Geneva, Switzerland.

Voegborlo, R. B., \& Akagi, H. (2007). Determination of mercury in fish by cold vapour atomic absorption spectrometry using an automatic mercury analyzer. Food Chemistry, 100, 853858.

Wagiyo Karsono \& Sri Turni Hartati. (2006). Biomassa dan keanekaragaman ikan di perairan Ancol, Teluk Jakarta. BAWAL. 1 (3): 83-87.

Wahyuningsih Tri, Maman Rumanta, Gusti Nurdin. (2015). Pencemaran $\mathrm{Pb}$ dan $\mathrm{Cd}$ pada hasil perikanan laut tangkapan nelayan di sekitar Teluk Jakarta. Seminar Nasional Konservasi dan Pemanfaatan Sumber Daya Alam: 105-111.

World Health Organization - WHO. (2005). Mercury in drinking-water. Background document for development of WHO guildlines for drinkingwater quality. WHO/SDE/WSH/05.08/10. p.10.

Yonvitner \& Zulhamsyah Imran. (2006). Rasio biomasa dan kelimpahan makrozoobenthos sebagai penduga tingkat pencemaran di Teluk Jakarta. Jurnal Ilmu Pertanian Indonesia. Vol. 11 (3): 1117. ISSN 0853-4217. 
